\title{
Neurological Evaluation of the Maturity of Newborn Infants
}

\author{
CLAUDINE AMIEL-TISON \\ From the Centre de Recherches Biologiques Néonatales, Hôpital Port-Royal, Université de Paris, France
}

Cerebral maturation during the last three months of fetal life brings about constant modification of muscle tone and of certain reflexes. This has enabled a scheme to be devised, whereby the neurological maturity of the premature infant at different ages can be assessed. Saint-Anne Dargassies (1955) defined this neurological progression by analysing a group of 100 prematures of known gestational age, and the longitudinal evolution of healthy prematures, born at 28 weeks' gestational age and studied up to 40 weeks' gestational age. The clinical results have been compared with the electroencephalographic (Dreyfus-Brisac, Flescher, and Plassart, 1962) and anatomical (Larroche, 1962) stages of development of the brain. In applying this maturation scheme to 'small-for-dates' babies it has been concluded that brain development during fetal life progresses independently of unfavourable gestational circumstances. Chronic fetal stress is reflected mainly in the birthweight and to a lesser degree in the body length at birth. The brain, however, from the point of view of anatomy and physiology, evolves more in proportion to the gestational age (Gesell and Amatruda, 1945; Bergström, Gunther, Olow, and Söderling, 1955; Saint-Anne Dargassies, 1955).

The original observations on which this paper is based are those of Minkowski, Larroche, Vignaud, Dreyfus-Brisac, and Saint-Anne Dargassies (1966). This paper presents a practical method for applying clinically the principles described by these authors. Butler and Bonham (1963) estimated that a third of infants weighing less than $2500 \mathrm{~g}$. have a gestational age greater than 38 weeks. The small-for-dates baby is liable to develop serious metabolic disturbance shortly after birth; for this reason it is imperative that the assessment of gestational age be made early. Occasionally the initial neurological evaluation of maturation is confused by signs of neurological disorders. But, as a rule, neurological examination during the first days of life can provide

Received May 22, 1967. data that are both precise and easy to evaluate. Physical criteria, such as the quality of the hair, the skin, and the plantar creases, can provide additional clinical evidence of maturity (Usher, McLean, and Scott, 1966; Mitchell and Farr, 1965; Farr, Mitchell, Neligan, and Parkin, 1966; Farr, Kerridge, and Mitchell, 1966).

\section{General Principles}

Saint-Anne Dargassies (1955) has applied to the premature baby the method of neurological examination described by Thomas (Thomas and Saint-Anne Dargassies, 1952; Thomas, Chesni, and Saint-Anne Dargassies, 1960). Appreciation of muscle tone is a fundamental feature in this examination, and includes study of the resting posture or attitude, 'passive tone', and 'active tone'. 'Passive tone' is appreciated by the physician applying certain movements to the infant who remains passive and at rest, while, for instance, the amplitude of passive movements of a single joint is measured. In contrast, 'active tone' is studied with the infant in an active situation, the physician noting, for instance, the righting reaction of the trunk when the infant is placed vertically.

Only those parts of the examination that are required to appreciate the infant's maturity are given in the Figures. The following notes are intended to supplement and clarify the tests set out in Fig. 1, 2, and 3. Gestational ages are calculated from the first day of the mother's last menstrual period.

\section{Passive Tone (Fig. 1)}

\section{Lower limb.}

Technique for the heel-to-ear manœuvre. With the baby lying flat on the table and keeping the pelvis flat on the table, lift the legs as far as possible and then attempt to touch the head with the feet. Observe the distance between feet and head (Fig. 1 (2)).

Popliteal angle measurement. Maintaining the pelvis flat on the table, flex the thigh at the hip to achieve a 


\begin{tabular}{|c|c|c|c|c|c|c|c|}
\hline & $\begin{array}{l}6 \text { months } \\
28 \text { weeks }\end{array}$ & $\begin{array}{l}6 \frac{1}{2} \text { months } \\
3 \text { Oweeks }\end{array}$ & $\begin{array}{l}7 \text { months } \\
32 \text { weeks }\end{array}$ & $\begin{array}{l}7 \frac{1}{2} \text { months } \\
34 \text { weeks }\end{array}$ & $\begin{array}{l}\text { 8months } \\
\text { 36weeks }\end{array}$ & $\begin{array}{l}8 \frac{1}{3} \text { months } \\
38 \text { weeks }\end{array}$ & $\begin{array}{l}9 \text { months } \\
\text { 4Oweeks }\end{array}$ \\
\hline I. POSTURE & $\begin{array}{l}\text { Completely } \\
\text { hypotonic }\end{array}$ & $\begin{array}{l}\text { eginning of } \\
\text { lexion of thigh } \\
\text { thip }\end{array}$ & $\begin{array}{l}\text { Stronger } \\
\text { flexion }\end{array}$ & $\begin{array}{l}\text { Frog-like } \\
\text { ottifude }\end{array}$ & $\begin{array}{l}\text { Flexion of the } \\
\text { four limbs }\end{array}$ & Hypertonic & $\begin{array}{l}\text { Very } \\
\text { hypertonic }\end{array}$ \\
\hline $\begin{array}{l}\text { 2. HEEL TO EAR } \\
\text { MANOEUVRE }\end{array}$ & & & & & & & \\
\hline $\begin{array}{l}\text { 3. POPLITEAL } \\
\text { ANGLE }\end{array}$ & & & & & & & \\
\hline $\begin{array}{l}\text { 4. DORSI- } \\
\text { FLEXION } \\
\text { ANCLE OF } \\
\text { FOOT }\end{array}$ & & & $a$ & & $\mathrm{O}_{40-0^{\circ}}^{\circ}$ & & $\begin{array}{l}\text { Premature } \\
\text { reached } 40 \text { wk. }\end{array}$ \\
\hline 5.'SCARF' SICN & $\begin{array}{l}\text { 'Scarf' sign } \\
\text { resistance }\end{array}$ & ete with no & 'Scarf' si & nore limited & $\begin{array}{l}\text { Elbow slight } \\
\text { midline }\end{array}$ & y passes & $\begin{array}{l}\text { Elbow almost } \\
\text { reaches } \\
\text { midline }\end{array}$ \\
\hline $\begin{array}{l}\text { 6. RETURN TO } \\
\text { FLEXION OF } \\
\text { FOREARM }\end{array}$ & \multicolumn{3}{|c|}{$\begin{array}{l}\text { Upper limbs very hypotonic } \\
\text { lying in extension }\end{array}$} & $\begin{array}{l}\text { Flexion of } \\
\text { forearms } \\
\text { begins to } \\
\text { appear, but } \\
\text { very weak }\end{array}$ & $\begin{array}{l}\text { Strong'return } \\
\text { to flexion'. } \\
\text { Flexion tone } \\
\text { inhibited if } \\
\text { forearm main } \\
\text { tained } 30 \text { sec } \\
\text { in extension }\end{array}$ & \multicolumn{2}{|c|}{$\begin{array}{l}\text { Strong 'return to flexion' } \\
\text { Forearm returns very } \\
\text { promptly to flexion after } \\
\text { being extended for } 30 \text { sec. }\end{array}$} \\
\hline
\end{tabular}

FIG. 1.-Passive tone. Increase of tone with maturity illustrated by means of 6 clinical tests.

knee-chest position. Holding the thigh in the kneechest position, lift the lower segment of the leg and observe the angle formed with the thigh, which is the popliteal angle (Fig. 1 (3)).

Angle of dorsi-flexion of the foot. In a full-term newborn at birth the foot can be fully dorsi-flexed. In a premature baby, only partial dorsi-flexion can be achieved. The angle of dorsi-flexion of the foot decreases during gestation, this explains the difference of position in automatic walking: a premature who has reached 40 weeks walks in a toe-heel progression or on tip-toes; a full-term 40 weeks' newborn walks in a heel-toe progression using the whole sole of the foot for support (Fig. 1 (4)).

\section{Upper limb}

'Scarf' sign ('signe du foulard', indicating that the arm encircles the neck like a scarf). Take the infant's hand and try to put it around the neck and as far posteriorly as possible over the opposite shoulder: in the full-term baby the muscle tone resists this manœuvre.
In the premature baby, the hypotonicity allows the elbow to be moved to the opposite shoulder (Fig. 1 (5)).

Return to position of flexion. In the mature baby, when the forearm is released after full extension at the elbow, it returns rapidly to a position of flexion. Maintain such extension for 30 seconds and observe the promptness of the return to flexion (Fig. 1 (6)).

\section{Active Tone (Fig. 2)}

Righting reaction of lower extremities and trunk. With the baby in the standing position, assess the support of body weight and the righting of the trunk (Fig. 2 (1 and 2)).

\section{Righting reaction of the head}

Neck extensors. With the baby sitting, and the head hanging down on the chest, move the trunk slowly backward and observe the reaction of the head; this allows the tone of the extensor muscles on the back of the neck to be tested (Fig. 2 (3)).

Neck flexors With the baby lying on the table, grasp 


\begin{tabular}{|c|c|c|c|c|c|c|c|}
\hline & $\begin{array}{l}\text { 6months } \\
28 \text { weeks }\end{array}$ & $\begin{array}{l}6 \frac{1}{2} \text { months } \\
\text { 3Oweeks }\end{array}$ & $\begin{array}{l}7 \text { months } \\
32 \text { weeks }\end{array}$ & $\begin{array}{l}7 \frac{1}{2} \text { months } \\
34 \text { weeks }\end{array}$ & $\begin{array}{l}8 \text { months } \\
36 \text { weeks }\end{array}$ & $\begin{array}{l}8 \frac{1}{2} \text { months } \\
38 \text { weeks }\end{array}$ & $\begin{array}{l}9 \text { months } \\
4 \text { Oweeks }\end{array}$ \\
\hline $\begin{array}{l}\text { 1. LOWER } \\
\text { EXTREMITY }\end{array}$ & - & $\begin{array}{l}\text { Beginning of } \\
\text { exfension of } \\
\text { lower leg on } \\
\text { thigh upon } \\
\text { stimulation of } \\
\text { soles in lying } \\
\text { position }\end{array}$ & $\begin{array}{l}\text { Good support } \\
\text { when standing } \\
\text { up but very } \\
\text { briefly } \\
\text { (see } \\
\text { illustration } \\
\text { below) }\end{array}$ & \multicolumn{4}{|c|}{$\begin{array}{l}\text { Excellent righting } \rightarrow-\cdots \\
\text { reaction of leg }\end{array}$} \\
\hline 2.TRUNK & - & - & - & $\frac{ \pm}{\text { transitory }}$ & $\begin{array}{l}\text { Good righting } \\
\text { of trunk with } \\
\text { infant held in } \\
\text { vertical } \\
\text { suspension } \\
\text { (see } \\
\text { illustration } \\
\text { below) }\end{array}$ & \multicolumn{2}{|c|}{$\begin{array}{c}\text { Good righting of trunk with } \\
\text { infont held in walking } \\
\text { position } \\
\text { (see } \\
\text { illustration } \\
\text { below) }\end{array}$} \\
\hline $\begin{array}{l}\text { 3. NECK } \\
\text { EXTENSORS } \\
\text { Baby pulled } \\
\text { bockward } \\
\text { from sitting } \\
\text { position }\end{array}$ & - & 一 & $\begin{array}{l}\text { Head begins to } \\
\text { right itself } \\
\text { with great } \\
\text { difficulty }\end{array}$ & $\begin{array}{l}\text { Still difficult } \\
\text { and incomplete }\end{array}$ & $\begin{array}{l}\text { Good righting } \\
\text { but connot } \\
\text { hold it }\end{array}$ & $\begin{array}{l}\text { Begins to main - } \\
\text { tain head which } \\
\text { doesn't fall back } \\
\text { for few seconds }\end{array}$ & $\begin{array}{l}\text { Keeps head in } \\
\text { line with trunk } \\
\text { for more than } \\
\text { a few seconds }\end{array}$ \\
\hline \multirow[t]{2}{*}{$\begin{array}{l}\text { 4. NECK } \\
\text { FLEXORS } \\
\text { Baby pulled } \\
\text { to sitting } \\
\text { position from } \\
\text { supine }\end{array}$} & $\begin{array}{l}\text { Head } \\
\text { pendulant }\end{array}$ & $\begin{array}{l}\text { Head } \\
\text { pendulant }\end{array}$ & $\begin{array}{l}\text { Contraction of } \\
\text { muscles is } \\
\text { visible but no } \\
\text { movement of } \\
\text { head }\end{array}$ & $\begin{array}{l}\text { Head begins to } \\
\text { right itself but } \\
\text { still hanging } \\
\text { back at end of } \\
\text { movement }\end{array}$ & $\begin{array}{l}\text { At first head is } \\
\text { hanging back, } \\
\text { then wifh } \\
\text { sudden move - } \\
\text { ment head } \\
\text { goes forward } \\
\text { onto chest }\end{array}$ & $\begin{array}{l}\text { Head begins to } \\
\text { follow trunk, } \\
\text { keeps in line } \\
\text { for few seconds } \\
\text { in upright } \\
\text { position } \\
\end{array}$ & $\begin{array}{l}\text { Difference } \\
\text { between } \\
\text { Extensors and } \\
\text { Flexors has } \\
\text { diminished } \\
\text { (see } \\
\text { illustration } \\
\quad \text { below) }\end{array}$ \\
\hline & & & $\begin{array}{l}\text { Straightening } \\
\text { of legs }\end{array}$ & & $\begin{array}{l}\text { Straightening } \\
\text { of trunk }\end{array}$ & & $\begin{array}{l}\text { Straightening } \\
\text { of head and } \\
\text { trunk together }\end{array}$ \\
\hline
\end{tabular}

FIG. 2.-Active tone. Increase of tone with maturity illustrated by means of 4 tests of righting reactions.

the hands (or the shoulders if a very small premature) and pull him slowly to the sitting position, observing the position of the head in relation to the trunk. This enables the tone of the flexor muscles on the front of the neck to be checked (Fig. 2 (4)).

The righting of the head on the trunk is observed first in the sitting position, then in the lying position. In a full-term baby, the difference between extensors and flexors of the neck has diminished; he will be able to keep his head from falling back for at least a few seconds.

\section{Reflexes (Fig. 3)}

Observation of the sucking and rooting reflexes, grasp reflex, and automatic walking requires no comment (Fig. $3(1,2,3$, and 6)), so that only two of the items set out in Fig. 3 require explanation.

Moro reflex (Fig. 3 (4)). A gentle technique is to be used with premature babies: lift the baby a few centimetres off the bed by holding both hands and suddenly let go. A complete reaction has three components: (i) Abduction and extension of the arms; (ii) opening of the hands; (iii) crying.

Crossed-extension reflex (Fig. $3(5)$ ). Rub the sole of one foot (left) while the same leg is held in extension and observe the response in the opposite (right) leg. The complete response has three components: (i) Extension of the right leg, after a rapid flexion or 'retreating'; (ii) adduction of the right leg, the right foot going toward the left foot (this adduction component only appears at 32 weeks); (iii) fanning of the toes.

\section{Discussion}

Passive tone (Fig. 1). This is responsible for the progressive development of the predominantly flexor posture of the newborn infant at term (Fig. 1 (1)). Muscle tone is completely flaccid at 28 weeks, increases first in the distal segments, to proceed in a caudocephalic direction. Flexor hypertonicity is generalized at term. The measurement of different limb-angles gives an objective measurement of passive tone; all these angles diminish as the muscle tone increases. The foot-leg angle seems to indicate relaxation of the passive tone of the posterior muscles of the leg. There is no satisfactory explanation of the difference in the foot-leg angles observed in the neonate born at 40 weeks' gestation and the premature having reached the gestational age of 40 weeks. 


\begin{tabular}{|c|c|c|c|c|c|c|c|}
\hline & $\begin{array}{l}\text { bmonths } \\
28 \text { weeks }\end{array}$ & $\begin{array}{l}6 \frac{1}{2} \text { months } \\
\text { 3Oweeks }\end{array}$ & $\begin{array}{l}7 \text { months } \\
32 \text { weeks }\end{array}$ & $\begin{array}{l}7 \frac{1}{2} \text { months } \\
34 \text { weeks }\end{array}$ & $\begin{array}{l}8 \text { months } \\
36 \text { weeks }\end{array}$ & $\begin{array}{l}8 \frac{1}{2} \text { months } \\
38 \text { weeks }\end{array}$ & $\begin{array}{l}9 \text { months } \\
40 \text { weeks }\end{array}$ \\
\hline $\begin{array}{l}\text { 1. SUCKINC } \\
\text { REFLEX }\end{array}$ & \multicolumn{2}{|c|}{$\begin{array}{l}\text { Weak and not really } \\
\text { synchronized with deglutition }\end{array}$} & $\begin{array}{l}\text { Stronger and } \\
\text { synchronized } \\
\text { with } \\
\text { deglutition }\end{array}$ & \multicolumn{4}{|c|}{ Perfect $\rightarrow$} \\
\hline $\begin{array}{l}\text { 2. ROOTING } \\
\text { REFLEX }\end{array}$ & \multicolumn{2}{|c|}{$\begin{array}{l}\text { Long latency period. } \\
\text { Response is slow and } \\
\text { imperfect }\end{array}$} & $\begin{array}{l}\text { Complete and } \\
\text { more rapid. } \\
\text { Hand-to-mouth } \\
\text { attraction } \\
\text { established }\end{array}$ & \multicolumn{4}{|c|}{$\begin{array}{l}\text { Brisk } \\
\text { Complete }-\rightarrow \\
\text { Durable }\end{array}$} \\
\hline $\begin{array}{l}\text { 3. GRASP } \\
\text { REFLEX }\end{array}$ & \multicolumn{2}{|c|}{$\begin{array}{l}\text { Finger grasp is good and } \\
\text { reaction spreads up whole } \\
\text { upper limb but not strong } \\
\text { enough to lift infant up off } \\
\text { bed }\end{array}$} & Stronger & Stronger & \multicolumn{3}{|c|}{$\begin{array}{l}\text { The reaction of } \\
\text { upper limb is strong } \\
\text { enough to lift } \\
\text { infant up off } \\
\text { bed }\end{array}$} \\
\hline $\begin{array}{l}\text { 4. MORO } \\
\text { REFLEX }\end{array}$ & \multicolumn{2}{|c|}{$\begin{array}{l}\text { Weak, obtoined just once, } \\
\text { and not elicited every time }\end{array}$} & Complete reflex & $x \rightarrow-\cdots$ & \multicolumn{3}{|c|}{$---\cdots,--\cdots \rightarrow$} \\
\hline $\begin{array}{l}\text { 5. CROSSED } \\
\text { EXTENSION }\end{array}$ & \multicolumn{2}{|c|}{$\begin{array}{l}\text { Flexion and extension in a } \\
\text { random pattern, } \\
\text { purposeless reaction }\end{array}$} & $\begin{array}{l}\text { Extension but } \\
\text { no adduction }\end{array}$ & $\begin{array}{l}\text { Still } \\
\text { incomplete }\end{array}$ & \multicolumn{3}{|c|}{$\begin{array}{l}\text { Good response with :- } \\
\text { 1. Extension }---\rightarrow \\
\text { 2. Adduction } \\
\text { 3. Fanning of the toes }\end{array}$} \\
\hline $\begin{array}{l}\text { 6. AUTOMATIC } \\
\text { WALKING }\end{array}$ & - & 一 & $\begin{array}{l}\text { Begins tip- } \\
\text { toeing with } \\
\text { good support } \\
\text { on sole and a } \\
\text { righting } \\
\text { reaction of } \\
\text { legs for a few } \\
\text { seconds }\end{array}$ & \multicolumn{2}{|c|}{$\begin{array}{l}\text { Pretty good } \\
\text { Very fost } \\
\text { Tip-toeing }\end{array}$} & \multicolumn{2}{|c|}{$\begin{array}{l}\text { - A premature who has reached } \\
40 \text { weeks. Wolks in o toe- } \\
\text { heel progression or tip-toes } \\
\text { - A full-term new born of } 40 \\
\text { weeks. Wolks in a heel-toe } \\
\text { progression on whole sole } \\
\text { of foot }\end{array}$} \\
\hline
\end{tabular}

FIG. 3.-Reflex. Development of reflex activity with maturity, illustrated for sucking, rooting, grasp, Moro, crossed extension, and automatic walking reflexes.

Active tone (Fig. 2). This is evaluated through the righting reactions, investigated segment by segment. At first only the righting of the lower extremities exists, and this is seen when the infant is held upright. Later the infant is able to sustain the weight of his body, and righting of the trunk occurs. Finally, the righting of the head becomes possible, by action of the neck extensors when the baby is inclined backwards from a sitting position; then, by action of the neck flexors, when the baby is pulled to sitting position from supine. The equality of flexor and extensor muscle tone in the neck in the neonate at term allows the head to be maintained momentarily in the line of the trunk. Finally, active tone is responsible for the quality of the primary reactions (or reflexes) (Fig. 3). At 28 weeks these reflexes are present but weak and difficult to elicit several times in succession. With increasing age, they become progressively stronger.

Difficulties in appreciating muscle tone. Robinson (1966) in his recent article on assessment of gestational age, states, 'the methods so far proposed for 'dating' babies by neurological examination have been insufficiently precise, or required too much experience in assessment of muscle tone, to be practicable for general use'. He has, accordingly, rejected muscle tone as an indicator of maturity, and instead has depended upon the presence or absence of certain reflexes, in particular, the pupillary reflex. It remains our contention that appreciation of muscle tone, following the scheme outlined above, should enable a paediatrician, after several months of practice, to differentiate short gestation from small-for-dates infants.

Optimal conditions for the examination. The examination immediately after birth should be followed by a second examination 2 or 3 days later, as the tone changes in the days that follow birth. The examination should be made when the infant is as wide awake as possible, for if the infant is sleepy the tone is much more relaxed and the primary reactions slow or absent. The best time is about an hour before feeding, when the infant is neither too sleepy as after a feed, nor too agitated while awaiting the next feed.

\section{Summary}

Neurological examination of the newborn infant is described, based on the evaluation of passive 
tone, active tone, and primary reflexes. Gestational age may thereby be assessed at birth, enabling short gestation infants to be distinguished from those that are small-for-dates.

I am deeply indebted to Dr. Saint-Anne Dargassies for the neurological teaching she gave me, and to Dr. $M$. Klaus for helpful criticism. This report was supported in part by U.S. Public Health Service Research Grant MO1 FR 81-04.

An educational film demonstrating this technique of neurological examination has been made by Minkowski (1965): 'Developpement du système nerveux central de la période fetale au terme'. Copies are available at 'Service du Film de Recherche Scientifique', 96 boulevard Raspail-Paris 6e.

\section{REFERENCES}

Bergström, A. L., Gunther, M. B., Olow, I., and Söderling, B. (1955). Prematurity and pseudoprematurity. Studies of the developmental age in underweight newborns. Acta paediat. (Uppsala), 44, 519.

Butler, N. R., and Bonham, D. G. (1963). Perinatal Mortality, table 47. Livingstone, Edinburgh.

Dreyfus-Brisac, C., Flescher, J., and Plassart, E. (1962). L'électroencéphalogramme: critère d'âge conceptionnel du nouveau-né à terme et prématuré. Biol. Neonat. (Basel), 4, 154.
Farr, V., Kerridge, D. F., and Mitchell, R. G. (1966). The value of some external characteristics in the assessment of gestational age at birth. Develop. Med. Child. Neurol., 8, 657.

—, Mitchell, R. G., Neligan, G. A., and Parkin, J. M. (1966). The definition of some external characteristics used in the assessment of gestational age in the newborn infant. ibid., 8, 507.

Gesell, A., and Amatruda, C. S. (1945). The Embryology of Behavior. Harper, New York and London.

Larroche, J. C. (1962). Quelques aspects anatomiques du développement cérébral. Biol. Neonat. (Basel), 4, 126.

Minkowski, A., Larroche, J. C., Vignaud, J., Dreyfus-Brisac, C., and Saint-Anne Dargassies, S. (1966). Development of the nervous system in early life. In Human Development, ed. F. Falkner, p. 254. W. B. Saunders, Philadelphia and London.

Mitchell, R. G., and Farr, V. (1965). The meaning of maturity and the assessment of maturity at birth. Little Club Clin. dev. Med., $19,83$.

Robinson, R. J. (1966). Assessment of gestational age by neurological examination. Arch. Dis. Childh., 41, 437.

Saint-Anne Dargassies, S. (1955). La maturation neurologique du prématuré. Étud. néo-natal., 4, 71 .

Thomas, A., Chesni, Y., and Saint-Anne Dargassies, S. (1960). The neurological examination of the infant. Little Club. Clin. dev. Med., 1.

- $\longrightarrow$ and Saint-Anne Dargassies, S. (1952). Études Neurologiques sur le Nouveau-né et le feune Nourisson. Masson, Paris.

Usher, R., McLean, F., and Scott, K. E. (1966). Judgment of fetal age. II. Clinical significance of gestational age and an objective method for its assessment. Pediat. Clin. N. Amer., 13, 835. 